\title{
A CLINICAL STUDY OF POSTMENOPAUSAL BLEEDING
}

\author{
Sarala Kuramu' ${ }^{1}$, P. Varsha Rani², Tejashree Shirale 3 \\ ${ }^{1}$ Associate Professor, Department of Obstetrics and Gynaecology, Mahavir Institute of Medical Sciences, Vikarabad. \\ ${ }^{2}$ Assistant Professor, Department of Obstetrics and Gynaecology, Patnam Mahender Reddy Institute of Medical Sciences. \\ ${ }^{3}$ Registrar, Yashoda Super Speciality Hospitals, Somajiguda, Hyderabad.
}

\section{ABSTRACT}

\section{BACKGROUND}

Menopause defined as permanent cessation of menstruation from loss of ovarian follicular activity. It is not just cessation of menstruation, it is "depletion of ovarian follicles" leading to decrease in ovarian hormones. Postmenopausal bleeding (PMB) is bleeding occurring after 12 months of amenorrhoea in women of age where the menopause can be expected.

The objectives of this study are-

1. To study the relative frequency of the different aetiological causes of postmenopausal bleeding.

2. To evaluate the different investigation procedures for the same.

\section{MATERIALS AND METHODS}

In postmenopausal women, detailed history was taken as per proforma, an informed consent was obtained. Gynaecological examination, pap smear and ultrasound were done. Most of the histopathology confirmed after examining hysterectomised specimens.

Design and Duration- Case control study of 50 postmenopausal women, done at the Obstetrics and Gynaecology Department, Kakatiya Medical College, Warangal, for 2 years duration.

\section{RESULTS}

In our study, $60 \%$ of pap smears were inflammatory and 14\% were positive for malignancy. In colposcopy guided cervical biopsy, $50 \%$ showed chronic cervicitis with $14 \%$ being malignant. In women with postmenopausal bleeding, majority were diagnosed with benign lesions i.e. Senile endometritis, endometrial hyperplasia, polyps, cervical erosion and prolapsed uterus.

\section{CONCLUSION}

Universal screening of all postmenopausal women with bleeding for genital tract malignancy is mandatory. Screening should be started effectively from reproductive age. Health education to all postmenopausal women is necessary to impact awareness on genital tract malignancy. Effective use of gynaecologist and community participation will ensure a good healthy life after menopause and prolongs life expectancy.

\section{KEYWORDS}

Menopause, Postmenopausal Bleeding, Universal Screening.

HOW TO CITE THIS ARTICLE: Kuramu S, Rani PV, Shirale T. A clinical study of postmenopausal bleeding. J. Evolution Med. Dent. Sci. 2017;6(77):5505-5508, DOI: 10.14260/Jemds/2017/1195

\section{BACKGROUND}

Abnormal vaginal bleeding is one of the most common presenting complaints encountered in gynaecological clinic. Among them postmenopausal bleeding ranks as the most sinister, as it is often associated with malignancy. Menopause is derived from Greek men (month) and pause (to stop), WHO defined menopause as permanent cessation of menstruation from loss of ovarian follicular activity. Postmenopausal bleeding (PMB) is bleeding occurring after 12 months of amenorrhoea in women of age where the menopause can be expected.

Postmenopausal bleeding is a common gynaecological problem seen in about $5 \%-10 \%$ of all gynaecological patients.

The differential diagnosis is usually limited to lesions in uterus, cervix, vagina, vulva, fallopian tube or be related to ovaries. The bleeding can be from non-gynaecological sites such as urethra, bladder and lower gastrointestinal tract.

Financial or Other, Competing Interest: None.

Submission 24-07-2017, Peer Review 12-09-2017,

Acceptance 19-09-2017, Published 25-09-2017.

Corresponding Author:

Dr. Sarala Kuramu

G-2, Woods Vale Apartment,

Madhura Nagar, Near Allahabad Bank,

Hyderabad, Telangana.

E-mail: skuramu@gmail.com

DOI: $10.14260 /$ jemds $/ 2017 / 1195$

\section{(c) $($ i) $\odot$}

The reported incidence of endometrial carcinoma has a very wide range from as low as $1.5 \%$ to as high as $54 \%$ in different population group. ${ }^{1}$

Thus, it warrants a thorough diagnostic evaluation, in order to identify the cause and to institute appropriate management at an early stage..$^{2,3}$

A woman not taking HRT who bleeds after the menopause has a $10 \%$ risk of having genital cancer and a further $10 \%$ risk of significant pathology. ${ }^{4}$

The risk of endometrial cancer at the age of 50 in a woman with postmenopausal bleeding is approximately $1 \%$ and rises to $25 \%$ at the age of 80 . Of women diagnosed to have endometrial cancer, more than $90 \%$ present with irregular peri-menopausal bleeding or postmenopausal bleeding. The incidence of significant pathology in woman with postmenopausal bleeding is only $20 \%{ }^{1}$

\section{Aims and Objective}

1. To study the relative frequency of different aetiological causes of postmenopausal bleeding.

2. To evaluate the different investigation procedures for the same.

\section{Need for Study}

As menopause signals the beginning of a period in life when risk for diseases such as cancer, coronary artery disease, stroke, osteoporosis etc., begin to increase. 
After menopause, total oestrogen production decreases by $80 \%$ and this has been linked to an increase in the risk of major as well as minor health problem in the postmenopausal women. ${ }^{5}$

Female genital tract will undergo various morphological and histological changes after menopause and it is one of the most common sites for primary malignant disease. ${ }^{6}$

It is important to bear in mind that all such pre-invasive lesions are by themselves completely asymptomatic, only routine screening will help detect these lesions. ${ }^{1,3}$

On global basis, breast cancer and cervical cancer are the two most common female malignancies.

In India, cancer uterine cervix is the most common killer and due to change in lifestyle and various other aetiological factors, cancer endometrium is on increasing trend. ${ }^{7}$

It is with this view that the present study is undertaken.

\section{MATERIALS AND METHODS}

This study entitled "A clinical study of postmenopausal bleeding," was done at CKM Hospital, Warangal in the Department of Obstetrics and Gynaecology, Kakatiya Medical College, Warangal.

\section{Inclusion Criteria}

All women of menopausal age who had 12 months of amenorrhoea and then has unscheduled vaginal bleeding are included in the study.

\section{Exclusion Criteria}

Postmenopausal women on HRT and known patients of genital tract cancer were excluded from the study.

\section{Methodology}

In all postmenopausal women, detailed history was taken as per proforma and an informed consent was obtained. Gynaecological examination, pap smear and ultrasound were done. Most of the histopathology is confirmed after examining hysterectomised specimens.

\section{Methods}

1. Papanicolaou test.

2. Ultrasonogram- A. Transabdominal, B. Transvaginal.

3. Colposcopy guided cervical biopsy.

4. Pipelle curette endometrial biopsy.

\section{RESULTS}

\section{The following observations were made-}

- Among the patients who have been admitted during the period from August 2010 to August 2012, majority of the patients were in the age group of 50 - 54 years.

- Maximum number of patients attained menopause at the age of 45 - 49 years.

- $\quad$ Most of the women had postmenopausal bleeding within 5 years of attaining menopause.

- Many gynaecological complaints like prolapsed uterus presented 9 - 10 years after attaining menopause.

- Many patients are parous women.
- Maximum number of patients had sudden cessation of menstruation.

- Inflammatory pap smears seen in many postmenopausal women indicating increased infections.

- In postmenopausal women, carcinoma cervix is high.

- Endometrium is not quiescent after menopause showing various patterns i.e. Atrophy, proliferation, endometrial polyps, infections leading to inflammations and neoplasia.

- Cervix is showing chronic non-specific cervicitis, polyps and neoplasia.

\begin{tabular}{|c|c|c|c|}
\hline $\begin{array}{c}\text { Age } \\
\text { (Years) }\end{array}$ & $\begin{array}{c}\text { CKMH } \\
\text { Study (\%) }\end{array}$ & $\begin{array}{c}\text { Kitnis } \\
\text { Study (\%) }\end{array}$ & $\begin{array}{c}\text { WH Lee } \\
\text { Study (\%) }\end{array}$ \\
\hline$<50$ & 22 & 11.2 & 6.1 \\
\hline $50-54$ & 30 & 27.6 & 31.2 \\
\hline $55-59$ & 14 & 24.3 & 29.4 \\
\hline $60-64$ & 14 & 14.5 & 14.1 \\
\hline$>65$ & 20 & 22.4 & 19 \\
\hline \multicolumn{4}{|c|}{ Table 1. Age Incidence } \\
\hline
\end{tabular}

The age of patients with postmenopausal bleeding varied from 40 - 70 years. Highest number of patients were in 50 59 years' age group.

\begin{tabular}{|c|c|c|}
\hline Parity & CKMH Study (\%) & Sengupta Study (\%) \\
\hline Nulliparous & 4 & 6 \\
\hline 1-2 children & 12 & 8 \\
\hline 3-4 children & 32 & 24 \\
\hline$>5$ children & 52 & 64 \\
\hline \multicolumn{2}{|c|}{ Table 2. Parity } \\
\hline
\end{tabular}

In present study $52 \%$ were grand multiparous and $4 \%$ were nulliparous, but on analysing it was found that parity has no significance as far as the cause of postmenopausal bleeding was concerned. Even those patients who had 1 or 2 children were found to have carcinoma of cervix and those who had 9 to 10 children were found to have benign lesions.

\begin{tabular}{|c|c|c|}
\hline Observations & Number of Cases & Percentage (\%) \\
\hline Negative smears & 5 & 10 \\
\hline Inflammatory smears & 30 & 60 \\
\hline Dysplasia & 5 & 10 \\
\hline Positive for malignancy & 7 & 14 \\
\hline Unsatisfactory & 3 & 6 \\
\hline \multicolumn{3}{|c|}{ Table 3. Pap Smears } \\
\hline
\end{tabular}

In our study of patients with postmenopausal bleeding in 5 patients, smear was normal. Maximum number of patients had inflammatory smear.

Sensitivity- $88 \%$, specificity- $100 \%$.

In most of the patients, visual inspection of cervix with Lugol's iodine was abnormal. 


\begin{tabular}{|c|c|c|}
\hline Biopsy Report & $\begin{array}{c}\text { Number of } \\
\text { Cases }\end{array}$ & $\begin{array}{c}\text { Percentage } \\
\text { (\%) }\end{array}$ \\
\hline Chronic cervicitis & 25 & 50 \\
\hline Endocervical polyp & 6 & 12 \\
\hline CIN-I, II & 5 & 10 \\
\hline CIN-III & 2 & 4 \\
\hline Squamous cell carcinoma & 6 & 12 \\
\hline Adenocarcinoma of cervix & 1 & 2 \\
\hline Table 4. Histopathological Findings of Cervical Biopsy \\
\hline
\end{tabular}

Maximum number of patients had chronic cervicitis. In our study, squamous cell carcinoma was seen in 6 cases with postmenopausal bleeding, 1 case with adenocarcinoma of the cervix.

\begin{tabular}{|c|c|c|}
\hline $\begin{array}{l}\text { Histopathology of } \\
\text { Endometrium }\end{array}$ & $\begin{array}{l}\text { Number } \\
\text { of Cases }\end{array}$ & $\begin{array}{c}\text { Mean Thickness } \\
(\mathrm{mm})\end{array}$ \\
\hline $\begin{array}{l}\text { Endometrial atrophy and no } \\
\text { curetting }\end{array}$ & 16 & 3.8 \\
\hline Hyperplasia & 6 & 12 \\
\hline Endometrial polyp & 3 & 10 \\
\hline Endometrial carcinoma & 4 & 18 \\
\hline Fibroid uterus & 2 & 8 \\
\hline $\begin{array}{l}\text { Postmenopausal uterus with } \\
\text { collection }\end{array}$ & 4 & 6 \\
\hline Others & 15 & 8 \\
\hline \multicolumn{3}{|c|}{$\begin{array}{c}\text { Table 5. Correlation between Histopathological Findings } \\
\text { and Thickness of Endometrium by Transvaginal } \\
\text { Ultrasound }\end{array}$} \\
\hline
\end{tabular}

Mean thickness of endometrium was $3.8 \mathrm{~mm}$ in cases with endometrial atrophy. In endometrial hyperplasia, it was $12 \mathrm{~mm}$. In endometrial carcinoma, it reached upto $18 \mathrm{~mm}$. Specificity- $80 \%$ and sensitivity- $85 \%$.

\begin{tabular}{|c|c|c|c|c|c|c|}
\hline Type of Endometrium & $\begin{array}{c}\text { CKMH } \\
\text { Study (\%) }\end{array}$ & $\begin{array}{c}\text { WH Lee } \\
\text { Study (\%) }\end{array}$ & $\begin{array}{c}\text { Kitnis } \\
\text { Study (\%) }\end{array}$ & $\begin{array}{c}\text { Sengupta } \\
\text { Study (\%) }\end{array}$ & $\begin{array}{c}\text { Israel and Weber } \\
\text { Study (\%) }\end{array}$ & $\begin{array}{c}\text { I. Bani } \\
\text { Study (\%) }\end{array}$ \\
\hline No curettings obtained & 10 & 13.5 & 53.3 & 68 & 42.6 & 12.8 \\
\hline Atropic & 36 & 52.1 & 19.1 & 10 & 23.4 & 51.9 \\
\hline Proliferative & 18 & 16 & 0.7 & 6 & - & - \\
\hline Secretory & - & 3.1 & 0.7 & 6 & 17.3 & 5.1 \\
\hline Polyp & 6 & - & 5.9 & - & 16.5 & 11.1 \\
\hline Hyperplasia & 12 & 3.1 & 5.9 & 2 & - & 9.2 \\
\hline Malignancy & 10 & 11 & 19.1 & 8 & - & 2.4 \\
\hline Inflammatory & 4 & 1.2 & - & & & \\
\hline
\end{tabular}

In present study, most of the patients with postmenopausal bleeding had atrophic endometrium. These include mostly cases with senile vaginitis, prolapse uterus and few cases with carcinoma of cervix and cervical dysplasia.

Curettings were not obtained in majority of the patients followed by atrophic endometrium. Inflammatory endometrium was found in $4 \%$ of the case study. In $18 \%$ of the patients with postmenopausal bleeding, endometrium was proliferative which included the cases of cystic glandular hyperplasia and atypical hyperplasia. 


\begin{tabular}{|c|c|c|c|c|c|c|c|}
\hline Lesions & $\begin{array}{c}\text { CKMH Study } \\
\text { (\%) }\end{array}$ & $\begin{array}{c}\text { WH Lee } \\
\text { Study (\%) }\end{array}$ & $\begin{array}{c}\text { Sengupta } \\
\text { Study (\%) }\end{array}$ & $\begin{array}{c}\text { Keirse } \\
\text { Study (\%) }\end{array}$ & $\begin{array}{c}\text { Nasira } \\
\text { Study (\%) }\end{array}$ & $\begin{array}{c}\text { Kitnis } \\
\text { Study (\%) }\end{array}$ & $\begin{array}{c}\text { MacFayden } \\
\text { Study (\%) }\end{array}$ \\
\hline Uterine malignancy & 10 & 11 & 8 & 13.7 & 8.9 & 9.2 & 14 \\
\hline Cervical carcinoma & 14 & 12.9 & 32 & 8.8 & 4.5 & 4.6 & 2 \\
\hline Ovarian cancer & 4 & 1.2 & 2 & 0.6 & 3.2 & 0.7 & - \\
\hline $\begin{array}{c}\text { Primary vaginal } \\
\text { carcinoma }\end{array}$ & - & 0.6 & - & 0.6 & 0.6 & - & - \\
\hline \multicolumn{7}{|c|}{ Table 8. Malignant Lesions } \\
\hline
\end{tabular}

In women with postmenopausal bleeding, incidence of malignancy in our study is $28 \%$. This shows an indication to screen all Indian postmenopausal women for malignancy of the genital tract.

\section{DISCUSSION}

50 patients presented with postmenopausal bleeding admitted in CKM Hospital were studied. All the cases were analysed and compared with various studies in the literature.

\section{CONCLUSION}

- In this study, majority of the patients reached menopause before 50 years of age. (Mean age 45 years).

- Pap smears and colposcopic appearance with Lugol's iodine can screen carcinoma cervix.

- Transvaginal ultrasound thickness of endometrium more than $5 \mathrm{~mm}$ with Pipelle curettage of endometrium is sensitive to detect carcinoma of endometrium.

- Benign lesions presented in combination with each other predominantly endometrial hyperplasia, polyp, prolapsed uterus, fibroid, erosion of cervix, cervical dysplasia.

- Many of the patients presented with postmenopausal bleeding, had benign lesions i.e. Senile endometritis, endometrial hyperplasia, vascular erosions of cervix, polyp, prolapsed uterus, cervical dysplasia.

- Inflammatory pap smears indicate infections with multiple organisms.

- Koilocytosis and acanthosis of cervix established human papillomavirus infection.

- The ratio of malignancy of cervix and endometrium is 2:1 in India.

- Endometrium has shown various changes after menopause i.e. Atrophic, proliferative, cystic glandular, polyp and carcinoma.

- Due to social taboos and illiteracy most of the women will not seek the medical assistance early, hence cancers have been reported at an advanced stage where survival chances are far less.

- In India, universal screening of all postmenopausal women for genital malignancy is mandatory by pap smear, colposcopic.

- Effective use of gynaecologists and community participations will ensure a good healthy life after menopause and prolongs life expectancy.

- The studies on geriatrics oncology have to be intensified.

- This study shows necessity to expand the presently available cancer control programmes, applying the modern technology to underprivileged rural women.

\section{REFERENCES}

[1] Kaur M, Singh R, Sharma M. Endovaginal sonographic evaluation of postmenopausal uterine bleeding. Journal of Clinical and Diagnostic Research 2010;4(2):2175-82.

[2] Bachmann LM, ter Riet G, Clark TJ, et al. Probability analysis for diagnosis of endometrial hyperplasia and cancer in postmenopausal bleeding; an approach for a rational diagnostic workup. Acta Obstet Gynecol Scand 2003;82(6):564-9.

[3] Breijer MC, Timmermans A, van Doorn HC, et al. Diagnostic strategies for postmenopausal bleeding. Obstet Gynecol Int 2010;2010:pp 5.

[4] Oehler MK, MacKenzie J, Kehoe S, et al. Assessment of abnormal bleeding in menopausal women: an update. J Br Menopause Soc 2003;9(3):117-21.

[5] Hill K. The demography of menopause. Maturitas 1996;23(2):113-27.

[6] Pacheco JC, Kempers RD. Etiology of postmenopausal bleeding. Obstet Gynecol 1968;32(1):40-6.

[7] Samartzis S, Hauser GH. Die Postmenopausenblu tung. Geburtsh Frauenhelikd 1976;36:326-33. 